\title{
UJI EFEKTIVITAS EKSTRAK BUAH KAWISTA (Limonia acidissima) TERHADAP PENURUNAN KADAR ASAM URAT DARAH PADA MENCIT JANTAN
}

\section{EFFECTIVENNESS TEST OF KAWISTA FRUIT EXTRACT (Limonia acidissima) IN REDUCTION OF BLOOD URIC ACID LEVEL ON MALE MICE}

\author{
Putu Rika Veryanti*, Ika Maruya Kusuma \\ Fakultas Farmasi, Institut Sains dan Teknologi Nasional \\ Jl.Moh Kahfi II Srengseng Sawah Jagakarsa Jakarta Selatan \\ *Penulis Korespondensi, e-mail: rika_veryanti@istn.ac.id
}

\begin{abstract}
ABSTRAK
Gout merupakan penyakit progresif yang ditandai dengan hiperurisemia akibat deposisi kristal monosodium urat di persendian, ginjal, dan jaringan ikat lain yang berlangsung kronik. Allopurinol merupakan terapi pilihan pertama pada gout kronik namun dapat memberikan reaksi obat yang tidak diinginkan bila digunakan dalam jangka waktu panjang. Buah kawista memiliki kandungan senyawa fitokimia seperti: saponin, tanin, alkaloid, flavonoid dan terpenoid yang bermanfaat untuk menurunkan kadar asam urat darah. Tujuan dari penelitian ini adalah untuk mengetahui efektivitas ekstrak buah kawista (Limonia acidissima) dalam menurunkan kadar asam urat darah pada mencit jantan. Penelitian ini dilakukan secara in vivo dengan menggunakan mencit jantan. Mencit diinduksi hiperurisemia dengan menggunakan hati ayam segar yang dibagi menjadi 5 kelompok yaitu kelompok yang diberi ekstrak buah kawista dosis 100 $\mathrm{mg} / \mathrm{KgBB}, 200 \mathrm{mg} / \mathrm{KgBB}, 400 \mathrm{mg} / \mathrm{Kg}$; kelompok kontrol positif (allopurinol) dan kelompok kontrol negatif (CMC-Na). Pemeriksaan kadar asam urat darah dilakukan 30 menit setelah diberi perlakuan. Hasil yang diperoleh menunjukkan bahwa ekstrak buah kawista (Limonia acidissima) pada dosis 100, 200 dan $400 \mathrm{mg} / \mathrm{KgBB}$ mencit dapat menurunkan kadar asam urat secara berturut-turut sebesar 26,67\%; 67,26\% dan 5,14\%. Ekstrak buah kawista dapat menurunkan kadar asam urat mencit dan dosis yang dapat menurunkan kadar asam urat terbesar adalah $200 \mathrm{mg} / \mathrm{KgBB}$.
\end{abstract}

Kata kunci: uji efektivitas, ekstrak buah kawista (Limonia acidissima), asam urat darah, mencit jantan

\section{ABSTRACT}

Gout is a progressive disease characterized by hyperuresemia due to the deposition of monosodium-urate crystals in the joints, kidneys, and other chronic connective tissue. Allopurinol is the first choice therapy for chronic gout but could give adverse drug reactions for a long time used. Kawista fruit contains phytochemical compounds such as: saponins, tannins, alkaloids, flavonoids and terpenoids which are thought to be useful for reducing blood uric acid level. This study was to determine the effectiveness of kawista fruit extract (Limonia acidissima) in reducing blood uric acid levels on male mice. This research was conducted in-vivo by using male mice. Mice were induced using fresh chicken liver and divided into 5 groups. There were groups of mice which treated by 
kawista fruit extract at a dose of $100 \mathrm{mg} / \mathrm{KgBw}, 200 \mathrm{mg} / \mathrm{KgBw}, 400 \mathrm{mg} / \mathrm{KgBw}$, positive control (allopurinol) and negative control (CMC-Na). After 30 minutes being treated, the level of blood uric acid was examined. The results showed that the extracts of kawista (Limonia acidissima) at doses of 100, 200 and $400 \mathrm{mg} / \mathrm{KgBw}$ of mice reduced gout levels respectively by $26.67 \% ; 67.26 \%$ and $5.14 \%$. The study concluded that the extract of kawista fruit significantly reduce uric acid levels $(p=0.00)$ with an optimum dose of 200mg/KgBw of mice.

Keywords: effectiveness, kawista fruit (Limonia acidissima) extract, blood uric acid, male mice

\section{PENDAHULUAN}

Gout merupakan penyakit kronik muskuloskeletal yang ditandai dengan penumpukan monosodium urat di persendian. Penumpukan kristal monosodium urat pada sendi dan jaringan lunak menyebabkan terjadinya peradangan dan rasa nyeri yang sangat mengganggu bagi penderita. Bila tidak ditangani, keadaan ini dapat berkembang menjadi gout kronik, gangguan fungsi ginjal dan dapat menurunkan kualitas hidup manusia (Indonesia, 2018).

Data epidemiologi dari beberapa wilayah di Indonesia menunjukkan prevalensi hiperurisemia dan gout di Indonesia lebih tinggi dibandingkan dengan negara-negara Asia lainnya. Data Riskesdas tahun 2013 menunjukkan bahwa prevalensi penyakit sendi di Indonesia berdasarkan diagnosis tenaga kesehatan sebesar 11,9\% dan berdasarkan gejala sebesar 24,7\% (Kesehatan, 2013).

Allopurinol merupakan salah satu pilihan terapi pada gout kronik. Allopurinol dapat menurunkan kadar asam urat di dalam darah dengan mekanisme penghambatan enzim xanthin-oksidase sehingga dapat mengurangi pembentukan asam urat. Namun pemberian allopurinol tidak dianjurkan secara rutin dengan pertimbangan risiko dan efektivitasnya. Beberapa reaksi obat yang tidak diingikan dilaporkan atas penggunaan allopurinol, diantaranya adalah gatal dan kemerahan pada kulit, perburukan fungsi ginjal, gangguan saluran cerna (mual dan diare), hati, hematologi dan reaksi hipersensitivitas (Lacy et al., 2017).

Bahan alam dapat dijadikan alternatif terapi pengobatan tanpa efek samping yang berbahaya untuk upaya mengatasi permasalahan di atas. Buah kawista (Limonia acidisimma) merupakan salah satu bahan alam yang sudah banyak diteliti dan terbukti bermanfaat bagi kesehatan (Rustiah and Umriani, 2018). Berdasarkan uji fitokimia, 
ekstrak etanol buah kawista mengandung berbagai senyawa aktif antara lain alkaloid, flavonoid, saponin, tanin, triterpenoid dan polifenol (Supriatno and Rini, 2018). Beberapa penelitian menunjukkan bahwa kandungan metabolit sekunder flavonoid dapat menurunkan kadar asam urat darah. Penelitian yang dilakukan (Himawan et al., 2017) membuktikan bahwa kandungan flavonoid pada tanaman suruhan (Peperomia pellucida) mampu menurunkan kadar asam urat darah tikus dengan efektivitas yang tidak berbeda signifikan dengan allopurinol sebagai kontrol positif (Himawan et al., 2017). Disamping itu, (Amir and Purukan, 2018) juga menunjukkan bahwa kandungan flavonoid yang terdapat pada buah naga puth (Hylocereus undatus) juga memiliki efek antihiperurisemia. Senyawa aktif lain yang juga diduga dapat menurunkan kadar asam urat darah adalah alkaloida dan triterpenoid. (Wajdie et al., 2018) menguji aktivitas antihiperurisemia dari ekstrak etanol daun kluwih terhadap mencit jantan.

Hasilnya menunjukkan bahwa ekstrak tersebut mengandung flavonoid, alkaloid dan triterpenoid yang dapat menurunkan kadar asam urat darah mencit sebesar 64,23\% pada dosis $112 \mathrm{mg} / \mathrm{Kg}$ (Wajdie et al., 2018). Buah kawista yang juga memiliki kandungan metabolit sekunder tersebut diduga memiliki potensi dalam menurunkan kadar asam urat darah. Berdasarkan uraian di atas peneliti tertarik untuk melakukan uji efektivitas ekstrak buah kawista (Limonia acidissima) terhadap penurunan kadar asam urat darah pada mencit jantan.

\section{METODE PENELITIAN}

Alat dan Bahan

Penelitian ini merupakan jenis penelitian eksperimental dengan menggunakan hewan coba mencit (Mus musculus). Mencit yang digunakan adalah mencit jantan yang berumur 2-3 bulan dengan berat badan 25-30 gram diperoleh dari Fakultas Kedokteran Hewan Institut Pertanian Bogor (IPB). Bahan-bahan yang digunakan untuk penelitian ini adalah buah kawista yang diperoleh dari Bogor, Jawa barat, allopurinol (Hexpharm Jaya), CMC-Na, metanol (Herbalux®), eter (Merck), H2SO4 (Merck), ekstrak hati ayam segar dan kertas saring. Alat yang digunakan adalah alat pendeteksi kadar asam urat darah (Easy Touch $\left.{ }^{\circledR}\right)$, spuit sonde (Terumo®) dan vacum rotary evaporator (Buchi B-740). 
Jalannya Penelitian

Pembuatan Ekstrak Metanol Buah Kawista

Sebanyak $2 \mathrm{Kg}$ buah kawista diiris tipis untuk kemudian dikeringkan dengan cara diangin-anginkan (tidak terkena cahaya matahari langsung) selama 7 hari. Selanjutnya daging buah diserbuk dan diayak menggunakan ayakan mesh 60 .

Ekstrak buah kawista diperoleh dari hasil maserasi dengan menggunakan metanol dengan perbandingan 1:1. Maserasi dilakukan selama 24 jam. Hasil maserasi disaring dengan menggunakan kertas saring sehingga menghasilkan filtrat. Filtrat selanjutnya diremaserasi dan dipekatkan dengan menggunakan vacum rotary evaporator pada suhu $50{ }^{0} \mathrm{C}$. Ekstrak yang telah dipekatkan diuapkan di atas waterbath hingga diperoleh ekstrak kental. Ekstrak kental disimpan pada wadah gelas yang tertutup rapat dan siap untuk dilakukan uji penapisan fitokimia. Uji penapisan fitokimia pada ekstrak buah kawista meliputi pemeriksaan flavonoid, alkaloid, saponin, tanin dan terpenoid (Gunarti, 2017).

Uji efektivitas ekstrak terhadap penurunan kadar asam urat darah

Sebelum dilakukan uji terhadap hewan coba, terlebih dahulu dilakukan pengurusan kode etik penelitian di Komisi Etik Penelitian Kesehatan, Fakultas Kedokteran, Universitas Pembangunan Nasional (UPN) Veteran Jakarta (Nomor: B/1791/4/2019/KEPK). Sebelum mendapatkan perlakukan, mencit diadaptasikan selama 7 hari dan 12 jam sebelum diuji, semua kelompok mencit dipuasakan kemudian diinduksi dengan $1 \mathrm{~mL}$ ekstrak hati ayam segar. Selanjutnya mencit dibagi menjadi 5 kelompok, masing-masing kelompok terdiri dari 3 ekor mencit jantan. Kelompok 1,2 dan 3 adalah kelompok uji dengan perlakuan pemberian ekstrak buah kawista dengan dosis berturut-turut 100, 200 dan 400 mg/KgBB mencit. Kelompok 4 adalah kelompok kontrol positif dimana mencit jantan diberikan allopurinol dengan dosis $10 \mathrm{mg} / \mathrm{KgBB}$ mencit dan kelompok 5 merupakan kelompok kontrol negatif yang diberikan plasebo CMC-Na.

Seluruh mencit diukur kadar asam uratnya dengan menggunakan alat pendeteksi kadar asam urat darah (Easy Touch®). Bagian ujung ekor mencit digunting sampai darah keluar. Darah disentuhkan pada bagian tepi samping strip hingga meresap dan terdengar suara "beep". Nilai kadar asam urat akan tampil pada layar sekitar 20 detik, 
kemudian dilakukan pencatatan kadar asam urat darah untuk masing-masing kelompok mencit. Selanjutnya mencit diinduksi dengan memberikan $1 \mathrm{~mL}$ ekstrak hati ayam segar secara per oral dengan menggunakan spuit sonde. Satu jam kemudian kadar asam urat darah mencit diukur kembali. Setelah itu, kelompok 1,2 dan 3 secara berturut-turut diberikan ekstrak buah kawista dengan dosis 100, 200 dan 400 mg/KgBB mencit per oral, kelompok 4 diberikan allopurinol $10 \mathrm{mg} / \mathrm{KgBB}$ mencit dan kelompok $5 \mathrm{CMC}-\mathrm{Na}$ $(1 \mathrm{~mL})$. Efektivitas ekstrak buah kawista terhadap penurunan kadar asam urat darah mencit diukur 30 menit setelah diinduksi dengan ekstrak hati ayam segar (Susilawati et al., 2019).

\section{HASIL DAN PEMBAHASAN}

Sebelum dilakukan uji efektivitas penurunan kadar asam urat darah pada mencit, ekstrak buah kawista diuji penapisan fitokimia. Uji ini dilakukan untuk mengetahui kandungan senyawa kimia yang terdapat pada buah kawista. Kandungan senyawa tersebut telah terbukti dapat dimanfaatkan dalam bidang kesehatan. Hasil uji penapisan fitokimia ekstrak buah kawista dapat dilihat pada Tabel I.

Tabel I. Data hasil uji penapisan fitokimia ekstrak buah kawista

\begin{tabular}{cc}
\hline Golongan Senyawa & Ekstrak Buah Kawista \\
\hline Saponin & + \\
Tanin & + \\
Alkaloid & + \\
Flavonoid & + \\
Terpenoid & + \\
\hline Keterangan : &
\end{tabular}

Tabel I menunjukkan ekstrak buah kawista mengandung berbagai senyawa kimia seperti saponin, tanin, alkaloid, flavonoid dan terpenoid. Senyawa tersebut diketahui dapat berfungsi sebagai antioksidan, hepatoprotektor, anti asam urat dan antibakteri (Raharja et al., 2016; Rustiah and Umriani, 2018; Supriatno and Rini, 2018).

Efektivitas ekstrak buah kawista terhadap penurunan asam urat darah pada mencit jantan ditampilkan pada Tabel II. Berdasarkan Tabel II dapat diketahui bahwa pemberian ekstrak buah kawista pada mencit jantan dapat menurunkan kadar asam urat darah secara signifikan $(\mathrm{p}=0,00)$. Hasil ini sejalan dengan kelompok kontrol positif yang diberi 
allopurinol $10 \mathrm{mg} / \mathrm{KgBB}$ mencit. Penurunan asam urat yang paling tinggi terjadi pada kelompok mencit yang diberi ekstrak buah kawista dengan dosis $200 \mathrm{mg} / \mathrm{KgBB}$. Penurunan asam urat terendah terjadi pada kelompok tikus dengan pemberian dosis 400 $\mathrm{mg} / \mathrm{KgBB}$. Tidak terjadi perubahan kadar asam urat darah yang signifikan pada kelompok kontrol negatif karena hanya diberi CMC-Na (plasebo) yang tidak memiliki efek sebagai anti asam urat.

Tabel II. Data hasil uji efektivitas ekstrak buah kawista terhadap penurunan asam urat darah pada mencit jantan

\begin{tabular}{ccccc}
\hline Perlakuan & $\begin{array}{c}\text { Rata-rata Nilai } \\
\text { Asam Urat } \\
\text { Mencit Sebelum } \\
\text { Perlakuan } \\
(\mathbf{m g} / \mathbf{d L})\end{array}$ & $\begin{array}{c}\text { Rata-rata Nilai } \\
\text { Asam Urat } \\
\text { Mencit Setelah } \\
\text { Perlakuan } \\
(\mathbf{m g} / \mathbf{d L})\end{array}$ & $\begin{array}{c}\text { Rata-rata } \\
\text { Penurunan } \\
\text { Asam urat } \\
(\mathbf{m g} / \mathbf{d L})\end{array}$ & $\begin{array}{c}\text { Persentase } \\
\text { Penurunan } \\
\text { Asam Urat } \\
(\%)\end{array}$ \\
\hline $\begin{array}{c}\text { Kontrol Negatif } \\
\text { (CMC-Na 1\%) }\end{array}$ & 3,13 & 3,10 & 0,03 & 0,96 \\
$\begin{array}{c}\text { Kontrol Positif } \\
\text { (alopurinol 10 }\end{array}$ & 3,58 & 1,23 & 2,35 & 65,64 \\
mg/KgBB) & & & & \\
Ekstrak 100 mg/KgBB & 3,45 & 2,53 & 0,92 & 26,67 \\
Ekstrak 200 mg/KgBB & 3,36 & 1,10 & 2,26 & 67,26 \\
Ekstrak 400 mg/KgBB & 3,69 & 3,50 & 0,19 & 5,14 \\
\hline
\end{tabular}

Uji efektivitas ekstrak buah kawista terhadap penurunan kadar asam urat darah, digunakan mencit jantan karena prevalensi gout lebih banyak terjadi pada pria dibandingkan wanita (13,6 permil vs 6,4 permil) (Indonesia, 2018). Mencit diinduksi dengan pemberian ekstrak hati ayam segar. Hati ayam adalah makanan dengan kandungan purin tinggi sehingga dapat meningkatkan kadar asam urat darah mencit (Fitrya dan Muharni, 2104). Mencit dinyatakan hiperurisemia bila kadar asam urat darah $>3 \mathrm{mg} / \mathrm{dL}$. Satu jam setelah pemberian ekstrak hati ayam segar, kadar asam urat darah mencit menjadi di atas $3 \mathrm{mg} / \mathrm{dL}$. Selanjutnya mencit diberi perlakuan ekstrak buah kawista pada dosis 100, 200 dan $400 \mathrm{mg} / \mathrm{KgBB}$ mencit. Sebagai kontrol positif digunakan allopurinol dengan dosis $10 \mathrm{mg} / \mathrm{KgBB}$ mencit. Pemilihan allopurinol sebagai kontrol positif karena allopurinol telah digunakan secara luas di pasaran dan terbukti efektif dalam menurunkan kadar asam urat darah. Asam urat adalah produk akhir dari metabolisme purin. Allopurinol bekerja dengan menghambat enzim xantin oksidase, dimana enzim tersebut dapat merubah hypoxanthine dan xanthine menjadi asam urat 
(Fardin et al., 2019). Sebagai kontrol negatif digunakan CMC-Na, dimana CMC-Na tidak memiliki efektivitas terhadap penurunan kadar asam urat darah.

Hasil penelitian menunjukkan bahwa ekstrak buah kawista dan allpurinol (kontrol positif) sama-sama dapat menurunkan kadar asam urat darah mencit. Hal ini disebabkan oleh kandungan kimia yang dimiliki oleh ekstrak buah kawista. Uji penapisan fitokimia menunjukkan ekstrak buah kawista positif mengandung saponin, tanin, flavonoid, alkaloid dan terpenoid. Senyawa kimia tersebut dapat menurunkan kadar asam urat darah pada mencit jantan. Flavonoid dapat menghambat aktivitas enzim xantin oksidase dengan mekanisme inhibisi kompetitif dan interaksi dengan enzim pada gugus samping (Lin et al., 2002). Alkaloid diduga sebagai inhibitor xantin oksidase dan xantin dehidrogenase sehingga dapat mencegah hiperurisemia pada tikus (Zhu et al., 2004). Dosis optimum ekstrak buah kawista dalam menurunkan kadar asam urat darah mencit adalah 200 $\mathrm{mg} / \mathrm{KgBB}$ dengan persentase penurunan kadar asam urat darah sebesar 67,26\%. Peningkatan dosis ekstrak dalam penelitian ini menunjukkan penurunan efek farmakologinya. Hal ini sering terjadi pada penggunaan ekstrak bahan alam sebab komponen yang terkandung di dalamnya bukan merupakan senyawa tunggal, namun terdiri dari berbagai senyawa kimia. Diantara senyawa kimia tersebut ada yang bersifat antagonis terhadap senyawa aktif sehingga menurunkan kemampuan ekstrak dalam menurunkan kadar asam urat darah (Apriani et al., 2016). Disamping itu, kemungkinan terjadinya interaksi antar senyawa kimia juga menjadi faktor penyebab terjadinya penurunan efektivitas ekstrak dengan dosis yang lebih tinggi (Sonia et al., 2020).

\section{KESIMPULAN}

Berdasarkan hasil penelitian dapat disimpulkan bahwa ekstrak buah kawista (Limonia acidissima) dapat menurunkan kadar asam urat darah mencit jantan $(\mathrm{p}<0,05)$ dengan penurunan asam urat terbesar terjadi pada dosis $200 \mathrm{mg} / \mathrm{KgBB}$ mencit.

\section{UCAPAN TERIMAKASIH}

Kami mengucapkan terimakasih kepada Kementrian Riset dan Teknologi Republik Indonesia, LLDIKTI wilayah 3 dan Lembaga Ilmu Pengetahuan Indonesia (LIPI). Penelitian ini didanai oleh Kementrian Riset dan Teknologi Republik Indonesia. 
Berdasarkan SK Nomor T/14/0E3/RA.00/2019 dan perjanjian/kontrak No 42/AKM/MONOPNT/2019. Penelitian ini termasuk dalam pemenang dana hibah tahun anggaran 2019 dengan skema Penelitian Dosen Pemula (PDP).

\section{DAFTAR PUSTAKA}

Amir, M., \& Purukan, J. I. A. (2018). Uji efektifitas ekstras etanol Buah Naga Putih (Hylocereus undatus) terhadap penurunan Kadar Asam Urat darah pada Mencit (Mus musculus). Jurnal Ilmu Kefarmasian Indonesia, 16(2), 166-171.

Apriani, A. A., Cahyo, W. P., \& Ibrahim, A. (2016). Efek antihiperurisemia ekstrak etanol daun Mahkota Dewa (Phaleria macrocarpa) Scheff. Boerl.) pada Mencit Putih (Mus musculus). Prosiding Seminar Nasional Tumbuhan Obat Indonesia Ke -50, 96-103.

Fardin, F., Desi, D., \& Onsi, R. (2019). Pengaruh pemberian allopurinol tablet dan probenecid tablet terhadap kadar asam urat darah kelinci yang diinduksi kalium oksalat. Jurnal Farmasi Fakultas Kedokteran Dan Ilmu Kesehatan UIN Alauddin Makassar, 7(1), 41-50.

Fitrya, F., \& Muharni, M. (2104). Efek Hipourisemia ekstrak ethanol akar tumbuhan tunjuk langit (Helminthostachys zaylanica Linn Hook) terhadap Mencit jantan galur swiss. Traditional Medicine Journal, 19(1), 14-18.

Gunarti, N. S. (2017). Uji pendahuluan dan karakterisasi buah kawista (Limonia accidisima) khas karawang,. PharmaXplore, 2(2), 136-144.

Himawan, H. C., Effendi, F., \& Gunawan, W. (2017). Efek pemberian ekstrak etanol 70\% tanaman suruhan (Peperomia pellucida (1). H.b.k) terhadap kadar asam urat darah tikus Spragua dawley yang diinduksi kalium oksonat. Fitofarmaka, 7(2), 7-14.

Indonesia, P. R. (2018). Pedoman diagnosis dan pengelolaan gout. Perhimpunan Reumatologi Indonesia, Jakarta. 
Kesehatan, B. P. D. P. (2013). Riset kesehatan dasar. Departemen Kesehatan, Republik Indonesia.

Lacy, C., Armstrong, L.L., Lipsy, R.J. and Lance, L. . (2017). Drug information handbook 26th ed. Lexi-Comp, United States.

Lin, C.-M., Chen, C.-S., Chen, C.-T., \& Liang, Y.-C. (2002). Molecular modeling of flavonoids that inhibits xanthine oxidase. Biochemical and Biophysical Research Communications, 294(1), 167-172.

Raharja, K. T., Wirjatmadi, B., \& Adriani, M. (2016). Pemberian buah kawista menghambat peningkatan kadar malondialdehid serum tikus wistar yang dipapar asap rokok. Jurnal Kedokteran Brawijaya, 29(3), 196-201.

Rustiah, W., \& Umriani, N. (2018). Uji aktivitas antioksidan dari ekstrak buah kawista (Limonia accidissima) menggunakan spektrofotometer UV-VIS. Indonesian Journal of Chemical Research, 6(1), 22-25.

Sonia, R., Yusnelti, Y., \& Fitrianingsih, F. (2020). Efektivitas ekstrak etanol daun durian (Durio zibethinus (Linn.)) sebagai antihiperurisemia. Jurnal Kefarmasian Indonesia, 10(2), 130-139.

Supriatno, S., \& Rini, A. A. (2018). Uji fitokimia dan antibakteri ekstrak etanol buah kawista (Limonia acidissima L.) pada bakteri Escherichia coli. Prosiding Seminar Nasional Pendidikan Biologi, 236-241.

Susilawati, E., Sukmawati, I. K., \& Abdullah, R. (2019). Aktivitas antihiperurisemia ekstrak etanol daun pepaya (Carica papaya L.) pada tikus putih jantan galur wistar. Jurnal Sains Dan Teknologi Farmasi Indonesia, 8(1), 27-34. 
Wajdie, F., Kartika, R., \& Saleh, C. (2018). Uji aktivitas antihiperurisemia dari ekstrak etanol daun kluwih (Artocarpus altilis (Parkinson) Fosberg) terhadap mencit jantan (Mus musculus). Jurnal Atomik, 3(1), 111-115.

Zhu, J. X., Wang, Y., Kong, L. D., Yang, C., \& Zhang, X. (2004). Effect of biota orientalis extract and its flavonoid constituens, quecetin and rutin on serum uric acid levels in oxonate-induced mice and xanthine dehydrogenase and xanthine oxidase activities in mouse liver. Journal of Ethnopharmacology, 93(1), 133-140. 